Rupkatha Journal on Interdisciplinary Studies in Humanities (ISSN 0975-2935), Vol. 10, No. 1, 2018 Special Issue on "Interrogating Cultural Translation: Literature and Fine Arts in Translation and Adaptation" In collaboration with the Department of English, Amrita Vishwa Vidyapeetham Guest-edited by Dr. Hari M G, Amrita Vishwa Vidyapeetham, Coimbatore, India DOI: https://dx.doi.org/10.21659/rupkatha.v10n1.06 Full Text: http://rupkatha.com/V10/n1/v10n106.pdf

\title{
Entwining the Omenala and Samskara: an Indo-Nigerian Ethnographic Study of Buchi Emecheta's Fiction
}

\author{
A. Karthika Unnithan ${ }^{1} \&$ Harini Jayaraman ${ }^{2}$ \\ ${ }^{1}$ Research Scholar, Department of English, Amrita School of Engineering, Amrita Vishwa \\ Vidyapeetham, Coimbatore, Tamilnadu, India.Email: alakkad.karthy@gmail.com \\ ${ }^{2}$ Professor, Department of English, Amrita School of Engineering, Amrita Vishwa \\ Vidyapeetham, Coimbatore, Tamilnadu, India
}

Received September 27, 2017; Revised December 11, 2017; Accepted December 30, 2017; Published February 04, 2018.

\begin{abstract}
Omenala is the Igbo word for the traditional religious practices and cultural beliefs of the Igbo people of southern Nigeria whereas Samskara is the Indian word for the cultural and traditional customs of India. The chosen topic for the study is the writings of a Nigerian author, Buchi Emecheta, since her novels reflect her Igbo heritage and represent Nigeria, more specifically Igbo society and who has also lived in her own indigenous culture and in London as well. The task at hand is an attempt at conducting an ethnographic study on the indigenous Igbo culture as seen in a few select novels of the author, simultaneously comparing it with the cultural features of India. The study also attempts to discuss the presence of cross-cultural practices as seen in the contemporary Nigerian society. The scope of study is restricted to only three of her works viz., Joys of Motherhood, Bride Price, and The Slave Girl. The basis of arguments in the study has been taken from Katherine Fishburn's interactive reading that demands reading across cultures and also reading our own selves. She, in her book Reading Buchi Emecheta: Cross-cultural conversations, mentions that to initiate a cross-cultural conversation with a novel, involves a give-and-take, "where I question it, and it questions me." (Pref.X). Fishburn further points out that "Though it is possible that we may never fully understand these alien practices, we may learn more of ourselves from our very inability to understand" (xiii). Based on this, a cultural study of Nigeria is taken upon in this paper while looking through the eyes of an Indian reader constantly comparing one with the other.
\end{abstract}

Keywords: Cultural-study, ethnographic-reading, Igbos, translation, Nigerian writings, amalgamation.

Simon Coleman and Bob Simpson, in their Glossary of Terms, define Ethnography as "the recording and analysis of a culture or society, usually based on participant-observation and resulting in a written account of a people, place or institution." Perhaps, ethnographic studies became more prominent with the need of the colonizer to understand people in their colonies. Usually, ethnographic studies deeply concentrate on a bound and definable group of people; for example, in this paper, the Igbos, a community mostly living in the south-eastern areas of Nigeria, will be mainly analysed, along with their various cultural and traditional aspects. Ethnographic texts offer an understanding of life in an unfamiliar environment, and also provide an insight into the political, economic and social dynamics of a particular ethnic community. The researcher aims at developing a deeper understanding of a particular culture including the cross-cultural

(C) Authors. Published by AesthetixMS under a Creative Commons Attribution Non-Commercial 4.0 International License (http://creativecommons.org/licenses/by-nc/4.0/). 
aspects of communities that are different from one's own. Asad Talal comments that an ethnographic project "consists not simply of looking-and-recording but of recording-andremaking and as such its discourses has sought to inscribe on the world a unity in its own image" (239).

In this paper, three works of Buchi Emecheta viz., Joys of Motherhood, Bride Price and The Slave Girl are considered for an ethnographic study as they are apt textual representations of Nigerian culture and her readers find her characters and their lives loyal to their community. Culture and gender are the two main instruments through which the review is carried out. Thus, a brief review of Igbo society, exhibiting the exclusive aspects inherent in Igbo culture, has been carried out and it is interesting to note that it is very much akin to the cultural practices of India with a few exceptions.

Nigeria is a melting pot of diverse ethnicities and a poly-ethnic nation - home to about 500 ethnic groups and languages. However, there are three dominant ethno-linguistic groups like Yorubas, Hausas and Fulanis.Traditionally, the Nigerians live in extended families where different generations live together close to one another and believe that they are bonded together by a common ancestor. Nigeria is essentially a patriarchal and patrilineal society where polygamy, slavery, and community living exist.

A close look at the cultural nuances that underlie the Igbo community is required before starting an actual study on this topic. Igbos is a group of people mostly living in the south-eastern areas of Nigeria and Oshu is one of the several social divisions among them. They were looked upon as social out-castes and were sub-human beings of the society. E. Pauline Aligweke, in the work The Continuity of Traditional Values in the African Society writes,

All communication with the rest of the society, whether at marriage level or habitation level, were forbidden to Oshu. It was preferred that the Oshu built their houses apart, far from the houses of the community. The Oshu lived generally, at the proximity of the altar of God to which they were consecrated. (153)

Igbo territories are referred to as Igbo land (Ala Igbo) and the people are referred to as Ndi-Igbo. The traditional Igbo extended family (Onuama) comprises numerous families residing within the same premises. The patrilineal and polygamous Igbo society preferred male children and they were more privileged and authoritarian than their female counterparts. Cultivation of yam, rearing of cattle mainly sheep and goats and extraction of palm-wine were some of the important activities of Igbo men. On the other hand, women cultivated coco-yam (a lower species of yam), reared chickens, and fetched water, firewood and did other household duties including cooking. Every Igbo individual has a personal God called Chi.

Buchi Emecheta has captured the above-mentioned Igbo practices and has effortlessly presented Nigerian perspectives throughout her writings. Her novels reflect the cultural overtones of a closed Igbo community and thus reveal the world of Igbos to the non-Igbo readers. In The Bride Price, for instance, she presents the alienation of the Oshu community in spite of the fact that the Oshus started climbing the social ladder during times of change in the mid-twentieth century. She makes a brief sketch of the social realities which were undergoing changes due to the implementation of the historic Act of Emancipation and the Abolition of Oshu law in 1956. This Act enables the Oshus to own land which was earlier denied to them and it also thwarts the customary legal disability that barred the Oshus from entering into any sort of land transactions. Possession of land indirectly empowers the community as a whole and raises their social status. In the novel, we find Chike's father Mr. Ofulue (an Oshu) purchasing a large area of land and using it 
for cultivation. Along with the rise in social status, we also find the Oshus, the first natives, receiving western education which leads to their occupying respectable positions. A few characters of the Ofulue family can be cited as instances to show the rising Oshus - Senior Ofulue, a former headmaster, a gynaecologist in the family, and Chike a middle school teacher. Emecheta has depicted the same social change in her novel Bride Price too: "In the olden days, slaves used to be sent there (to missionary schools) simply to appease the disapproval of the white missionaries; but later events were to show that it was these same educated slaves who ended up commanding key position."(74)

However, the social humiliation that was attached to be an Oshu couldn't be erased from the minds of the freeborn. A free born Igbo woman is discouraged from choosing an Oshu as her husband. The women entering such unacceptable marriages were prophesied to be either unable to conceive or to die during childbirth. But Aku-nna, the protagonist, attempts to defy the Ibuza tradition by falling in love with Chike and finally marrying him. Her bold attempt to challenge the ancient Igbo laws is deeply resented by the members of her family and village community of Ibuza. Her furious step-brothers take a pledge to terminate the intolerable love-affair. They say, "The son of Ofulue? You mean Chike, the school teacher? But he is the son of slaves... She could be interested in him to that extent!" He admonishes the act and warns her by saying, "I will kill her if this is true", Osenekwu swore to himself. (BP, 79) When the news of Aku-nna's sexualmaturity reaches Okonkwo (Aku-nna's step-father), he is impelled to have a patriarchal talk with her: "Aku-nna, Chike Ofulue is only a friend... Now that you have grown, that friendship must gradually die. But die it must!" (BP, 116) Upon learning about the apparent love-affair between Aku-nna and Chike, Aku-nna's mother reacts intensely: "Ma Blackie cried and cursed her fortune in being saddled with such a daughter. Had they even seen a girl like this daughter of hers. Who was wanted by so many good families but who preferred to choose a common..." (BP, 121)

Such biases deeply entrenched in the minds of the freeborn prevent them from maintaining cordial relations with the Oshus. Further in the novel, the vengeful destruction of Ofulue's plantation (to avenge his help in the elopement of Chike with Aku-nna) highlights the unethical schemes that are plotted against Chike's (Oshus) family for their boldness in disobeying the laws of the land. This instance of illegitimate damage shows that the two communities could not co-exist peacefully and maintain cordial social relations. But the modern judiciary, based on the system of equality "did not make allowance for the slaves, so the Ibuza people lost the case and were ordered to compensate the Ofulue family in kind. The free men had to plant new cocoa for the slave and heavy fines were duly paid." (BP, 155)

It is strikingly similar that such rigidities of culture are often found among Indian communities too and at times even educated people living in urban India do not want to break away from the ethnic and moral bonds. Unfortunately, such hard-core stance leads to honourkillings - one of the evils of our society. One of the most popular and frequent themes in Indian literature throughout the twentieth century is 'frustrated love' mainly due to the rigidities of caste endogamy. It is a living institution all over India; irrespective of all religions; endorsed by all who accept the principle of arranged marriage. Any exercise of one's own choice in selecting one's partner is interpreted as defiance to patriarchal authority and a threat to endogamy. Krishnaswamy and Kamath in their article mention thus:

In India marriage is viewed as an event of great social and religious significance which marks the first stage in family building process. Almost all marriages cutting across caste and class stratification are arranged and caste endogamous. Marriages are mainly arranged by elders in the family, even though the concerned young person has a say in the final 
selection of his/her companion or rather his/her opinion as sought by elders before finalizing the partner selection. Thus, the choice of spouse limited by caste endogamy remains still largely a matter of negotiations and decision by family elders. Thus, marriage is considered not simply as an alliance between the two individuals but as an alliance between two families. The family background factors of the boy and girl are thoroughly examined by parents before finalizing the alliance, as marriage alliance is thought to be of great importance to family relations. As such an individual's views and feelings regarding inter-caste marriage are likely to be more influenced by how such a marriage would affect one's parental family and one's relation with one's parental family. Class status among Indian community is preserved mainly by the caste endogamy which has a stronghold on spouse selection in the institutions of marriage. Even though the number of inter-caste marriages and acceptance to such marriages is slowly increasing, the hold of caste is still an evident factor regarding mate selection. K.M. Kapadia has pointed out that, "even though inter-caste marriage is slowly accepted and there are factors operating in favour of inter-caste marriages, it cannot be said that the inter-caste marriages are welcome in our caste-ridden society. At best they are tolerated. "What Kapadia has said is found to be true even after half a century, as can be seen by simply going through matrimonial ads, most of which still state the requisite caste or sub-caste of the bride or groom needed."(129)

Social reformers and Hindu Reformist Movement led by Brahmo Samaj and Arya Samaj observed inter-caste wedding as an important way for changing and demolishing caste system. Although progressive laws such as Special Marriage Act 1954 were passed, even today inter-caste married couple face problems which other couples are not required to face.

On the subject of love and marriage, Emecheta's novel also casts information on various types of marriages and wedding customs practiced in Ibuza. When Aku-nna's father dies, her mother is inherited in marriage by her father's elder brother in accordance with the customary law of 'widow inheritance' - an accepted form of marriage in Nigeria. The reason has been explained by the narrative voice: "It is so even today in Nigeria: when you lost your father, you lost your parents... A fatherless family is a family without a head, a family without shelter, a family without parents, in fact a non-existing family." (BP, 28). K.P.Chattopadhyay in his article Levirate and Kinship in India mentions the concept of a widow remarried to her husband's brother which is stated in Rig Veda $(\mathrm{X}, 18.8)$ "where the brother of the deceased husband takes the widow by the funeral pyre by the hand and asks her to rise up and leave the dead" (37). He also points out that the same custom known as niyoga is described in Manu Samhita (IX, 59-63), in which a widow who is childless, has to be the mother of an offspring from her devara (second husband/ brother in - law) or through some, sapinda or sagotra (husband's lineage) and accordingly consider her as the daughter-in-law of the same family ever afterwards (37). Even though, in modern practice the custom has practically disappeared from the higher strata of Hindu society it is, however, almost universally prevalent in other lower strata all over India.

In contrast to Indian traditions, Igbo traditions are a mix of their own tribal customs along with a few Christian rites- be it marriage, funeral or any other religious ceremonies. In the beginning of the novel, we find a curious custom of a bride-groom cutting a lock of hair from the bride's head- Ezikel Odia (Aku-nna's father) cuts a lock of curl from Ma Blackie's hair. The significance of this ritual according to the Igbo culture, is to suggest that the woman should permanently belong to a man who had cut a lock of hair from her head. Later on, Ma Blackie's daughter Aku-nna imagines about a marriage which would be a mix of both traditions: "She would have her marriage first of all solemnized by the beautiful goddess of Ibuza, then the 
Christians would sing her a wedding march... then her father would call up the spirits of his great, great grandparents to guide her..." (BP, 10)

Not only are the marriage ceremonies, even the funeral procedures are a mix of traditional observances and European customs. When Aku-nna's father passes away, as per the Igbo tradition, mourners are hired: "There were expert professional criers who listed the good deeds performed by the departed and tactfully left out the bad. His lineage would be traced out loud, the victories of his ancestors sung and their heroic past raised to the winds." (BP, 29) There would be distribution of Kolanuts followed by singing Christian hymns in Igbo language.

Leaving aside the Christian customs, we cannot but miss the similar type of mourning customs that are prevalent in some parts of Rajasthan, especially in the Jaisalmer region- where aristocratic veiled women were kept secluded in their chambers and prevented from participating in mourning publicly. In place of these ladies, female griever(s), a rudaali (a woman who is hired for weeping) was brought in for funeral ceremonies, to unmistakably express the grief that the near relatives, obliged by their high economic wellbeing, were not allowed to show. To express grieving, a rudaali dresses herself in dark with hair let free, and cries out loud and sings in acclaim of the deceased. It is fascinating to note that, in South India as well, particularly in Tamilnadu, ladies gather around with open hair, sing their distresses through such melodies, and tell how they miss the departed, at the same time singing in praise of the accomplishments of the dead person. Such tunes are set to a specific tone and cadence. Music being an indispensable part of Tamil culture, we find that for each event there is a specific sort of music; from the day of birth to the last breath. From Thalatu (lullaby) to the final Oppari (bewail) every part of life of Tamilians is loaded with music.

When Ma Blackie comes to know about Aku-nna's first menstrual period, she informs her daughter about the do's and don'ts of womanhood in their culture. This event is publicly celebrated by the girl's family. The girl's body was daubed with free hand designs in deep black or red colour made of camwood dye (uhie). Waist beads called jigida, anklets and ivory necklaces were also worn by Igbo girls. For most of the Igbo girls, menarche is synonymous with the rite of seclusion, generally known as $n k p u$. "She must not go the stream; she must not enter her stepfather's house, nor the house of any Eze chief until it was all over." (BP, 115) Among Igbos, at the time of first menstruation cycle itself a girl is instantly made ready for marriage, and her parents keep her in seclusion for eight days. It was believed that nature proclaimed her as a woman, and her hand could be asked in marriage. Prior to the European influence, traditionally, preparation for marriage began in childhood and was concluded on the wedding day. (Okorike, 105)

In parallel, the researcher observes that in India too similar customs exist. Ritu shuddhi also known as Ritu Kala Samskara, is a Hindu tradition associated with a girl's attaining of puberty. Although, puberty is considered as a positive aspect of a girl's life, women who are menstruating are kept in confinement and are not allowed in the precincts of a temple or even inside a kitchen. Although the rituals may differ from one place to another, in general, puberty ceremony is celebrated by inviting relatives and friends. This ends with the particular goal of declaring to the whole world that there is a young lady of eligible age. The girl is dressed up like a lady, she is gifted her first silk saree and is decked up with adornments and flowers. After the young lady gets prepared, she is made to sit on a wooden seat, where a priest performs some cleansing rituals. Post the rituals and customs, the young lady is again given a shower with special water blended with turmeric powder and neem. 
Barrenness and child bearing were the other cultural taboos that caused humiliation and mental agony to the Igbo women. Victims of infertility even committed suicide. Nnu Ego wishes to meet her Chi (personal god) that she believes condemned her to childlessness. While trying to jump to death from the Carter Bridge, she thinks that now "... she would be able to seek out and meet her Chi, and then she would ask her why she had punished her so."(JOM, 9) Nnu Ego's anguish at being barren resonates the cultural commitments that lower women's self-respect. To dismiss the supposed curse of Chi, that rendered her barren, Nnu Ego desperately went from one dibia (medicine man with divine powers) to another in hope of breaking her Chi's spell so that her husband would refrain from entering another marriage. Her torment illustrates the pathos of barren women in Igbo society. Nnu Ego's first husband humiliates her when she fails to conceive during the first year of marriage. Nnu Ego would take an egg, symbol of fertility, and kneel and pray to Chi to give her a son. She would say, "Please, pity on me. I feel that my husband's people are already looking for a new wife for him. They can't wait for me forever. He is the first son of the family and his people want an heir from him as soon as possible. Please help me." (JOM, 32) He throws her out of his hut and gets a new wife. Disgraced Nnu Ego is labelled as a 'failed woman' by the society. Emecheta brings much attention to the ideologies of patrilineal culture in which womanhood is associated with motherhood and a woman's primary role is to render immortality to her husband by extending his lineage, that is, by producing sons. Her inability to execute the role caused terrible mental anguish to the woman concerned. Igbo culture maintains that a woman without a child for her husband is an unsuccessful woman and we see this idea resonating in the words of the women of Amatokwu's family, when they agree "that a woman without a child for her husband is an unsuccessful woman." (JOM, 62) So Nnu Ego's harmonious relation with Amatokwu fades away as she fails to get pregnant. Amatokwu denies her attention and love and bluntly tells her "I have no time to waste my precious male seed on a woman who is infertile." (JOM, 32) Though she "shed tears in her heart", yet promises herself that she will never return to her father's house as a 'failure' - a woman who cannot conceive babies. Her frustration at being barren, a condition that is being considered demeaning for Ibuza women implies her belief in customs that heap upon her. Disturbed by the disgrace of infertility, she tells her first husband "Iam sure the fault is on my side. You do everything right." (JOM, 31) Nnu Ego's habit of blaming herself for childlessness illustrates her slavish acceptance of patriarchal values. Her plight illustrates the meaning of Adrienne Rich's concept of the 'institution of motherhood' in $O f$ Woman Born: Motherhood as Experience and Institution (1976) in which she combines her own experience as a mother with feminist theory. Rich is of the view that patriarchy uses motherhood as an instrument for making women powerless. Upon her return from her first husband's house, she agrees for a second marriage as she firmly agrees with the Ibuza ideology that, "When one grows old, one needs children to look after one. If you have no children, and your parents are gone, who can you call your own?" (JOM, 38) To juxtapose this with Indian scenario, where a barren woman is ridiculed and ostracized, the words of Dr. Devdutt Pattanaik in his article Infertility in Hindu Mythology are cited here:

A barren woman has been cursed by God and being punished for the sins of a prior life. Hindus believe that all men come into this world burdened by a debt - the pitr-runa (pitr = ancestor; runa $=$ debt). The only way to repay this debt is to father a male offspring. During funerary rites, known as shraadha, Hindu males are reminded of this debt. In the Dharmashastras, Hindu law books written between 500-1000 A.D., it is said that those who fail to repay this debt end up in the Hell where they suffer for all eternity. Since the birth of a child, preferably male child, liberates a man from his debt, the Sanskrit word for son is putra. Men who could not fulfil their biological obligations because of a physical 
problem (impotence) or a mental quirk (homosexuality) were termed rather derogatorily kliba or napunsaka, sexually dysfunctional non-man. In the Manu Smriti, an ancient Hindu law book, such men were debarred from sacred rituals and from inheritance. Only by producing children, were a man and woman considered biologically fulfilled. It must be remembered, that only after marriage was a man in Hindu society given the right to enjoy worldly pleasures and possess worldly wealth.

Like Nnu Ego in JOM, Indian women who are infertile experience the dishonour of barrenness. During Aryan civilization, barren women were cast away as parivrikti. In her Encyclopaedia of Indian Women through the Ages: Ancient India, Simmi Jain remarks:

A barren woman was considered to be an abominable creature, was most pitiable in Aryan family system. It is ordained that 'A barren woman could be cast away (parivritti or parivrikti) because she was possessed by Nirtti... The husband of a sonless wife should marry again. The definition of good women is one who pleases her husband, gives birth to male children and never speaks back to her husband. The poignant desire to avoid the slur of sonlessness or the stigma of barrenness is a universal phenomenon. All over the world down the ages women have craved for sons and have practised austerities, observed vows, prayed and supplicated for fertility. Childlessness has been regarded as a great misfortune. (172)

As in India, as well as in Igbo community, a woman's position in a family depends upon the number of children that she gives birth to. In the very beginning of the novel The Bride Price Emecheta yet again stresses upon the desire of Igbo women to mother as many children as possible and failure to do so caused despair to the husband and wife, and the son-in-law complains to Ma Blackie that having paid a heavy bride price he had only one son. This problem of childlessness caused agony to infertile woman as the women in the village sang songs of ridicule about the infertility of that woman. "Many a time she had heard other women living in the same compound make songs of her childlessness." (BP, 9) In order to overcome the curse of childlessness of her daughter Ma Blackie, as a form of worship: -

Was to stay in Ibuza and have her system purified by the clear and unpolluted water from the Oboshi River; the river and the goddess of the river were gift to all the Ibuza people from the greater Gods. It was the right of all Ibuza sons and daughter to come and have them cleansed by the river when they found themselves in difficulties in distant places of work. (BP, 47)

This apparently has a parallel in the Indian beliefs of getting oneself blessed by immersing oneself in Holy rivers like Ganga. Cleansing in these rivers is considered to be a form of purifying oneself from their sins.

The obsession to have children, especially male children is apparently seen in most of the works of Nigerian writers and Buchi Emecheta in particular. In the novel Joys of Motherhood Nnu Ego desperately pleads to God for a male child. In India too most families prefer boys for continuing the lineage. The African women's craving for male child comes from the traditional belief that the lineage of husband will expand and be remembered only if they have male children/ only through male children. Many childless women pray to Oboshi River to grant a child. In the novel Slave Girl Ukabegwu says, "There are some of us left on the work of producing more and more children. And that is why Iam now begging our mother of the Oboshi river, the great guardian of the Eke market and your Chi to give you a male child, so that the name of your husband can be remembered." (SG, 77) They even want the Gods to spare the death of male 
children. When Ibuza was in the grip of felenza, prayers were offered to God to spare the boys. "Let us pray to God to spare him for us so that he may live and be great man, a great hunter and a great Obi." (SG, 77) Igbo women long to have a male child who would take care of his old parents and relatives, live in the same compound and extend their lineage. Nnu Ego dreamt of having a grown-up son "who would live next door to her, whatever profession he choose, as a good son should live near his parents and look after them and she would see to the growth and welfare of his children and wives." (JOM, 79) When her brother Okolie seals her fate by selling her into slavery and even defends his decision, one of his aunts says, "So was not her brother the rightful person to decide the fate of little Ojebeta?" (SG, 78) A girl was to be guided all her life by her father, brother, husband and the other male relatives and in old age had to depend on her son. After years of being owned by men, women consider the condition of being owned by men as a matter of pride. Ojebeta's aunt Uteh consoles her by saying that "To be owned by a man is a great honour." (SG, 157) She further says that Okolie's act of giving his sister to slavery should be forgiven as Okolie "has the right to sell you or borrow money on your head or spend your bride price. So you must forgive Okolie." (SG, 158) Besides, a woman must have brothers to support her in times of trouble.

Regardless of the caste, gender roles remained the same throughout. Such notions are not alien to Indians because our families also mostly prefer boys to girls and we also believe in the ideology that boys continue the lineage. In Manusmriti, a woman's status is clearly defined as thus - she must be under her father's care during childhood, in her youth she must be controlled by her husband, and during old age yielding to her sons and thus a woman must always be dependent.

The plight of women in Nigerian culture is even worse when it comes to master-slave relationship. In JOM, the slave girl who refuses to go down like a good slave with her dead mistress is given a heavy blow on her head by the mistress's son to send her silently into his mother's grave as part of their custom during pre-independence. It symbolizes the suppression of Igbo women who are buried alive as part of the rigid orthodox culture of their societies. Emecheta explicitly portrays such strong tradition of patriarchy in her works through her female characters. Florence Stratton, in her article The Shallow Grave: Archetypes of female experience in African Fiction, writes:

Her female characters are enclosed in the restricted spheres of the behaviour of stereotypes of male tradition, their human tradition buried in shallow definitions of sex. Silenced like the slave woman, by blows either to bodies or their psyches- they are forced to submit to the necessity of conforming to the externally imposed requirements of their masculine societies. (100)

The researcher does not find any parallels for the above in Indian cultural practices.

Notwithstanding the plights mentioned above, even within marriage the man-woman relationship is at times problematic. The account of Adah and Francis' reunion at London in the novel Joys of Motherhood does not imply restoration of cordial spousal relations. The narrative voice says: "Adah did not remember in the confusion that her nickname at home was 'touch-not.' But how could she protest to a man who was past reasoning. The whole process was an attack, as savage as that of an animal." (SCC, 40) The re-union as an attack counters any idea of harmonious relationship between them and confirms a case of sexual violation. At the end of the unpleasant act Francis abuses Adah for her resistance and unresponsiveness in the sexual act. All these occurrences can be taken as ample evidences against Francis who was raised by a culture that validates male supremacy. So, Francis, instead of providing support to Adah, on the contrary acts 
adversarial. Similarly, Adah since her childhood, had been a sufferer of bitter experiences directed to her in the form of disapproval of girl's education; by her cousin in the process of her physical abuse; and finally, her objectification by her mother and uncle in their intention to marry her off to the highest bidder of bride price. Therefore, after marriage Adah lets traditions and Francis enslave her. This self-imposed slavery encourages Francis to commit more acts of brutality on her. Many of Emecheta's female characters encounter domestic abuse and marital rape. Problems like domestic violence and marital rape is widespread in Indian society also. L. Gerstein, in his essay In India, Poverty and Lack of Education are Associated with Men's Physical and Sexual Abuse of Their Wives, says thus:

Domestic abuse is common in India, but varies widely by region. In a study conducted in five districts of Uttar Pradesh, 18-45\% of husbands reported physically abusing their wives. Of those who acknowledged being physically abusive, more than four in 10 reported an episode of violence during the prior year and more than six in 10 admitted repeated abuse. Men who had little education, those who had more than one child and those who were extremely poor were more likely than other men to have physically abused their wives. In separate analyses of these data examining relationships between wife abuse and male reproductive health, the prevalence of abuse was significantly higher among men who had had extramarital or premarital sex, those who had ever had a sexually transmitted disease (STD) and those whose wives had had an unplanned pregnancy than it was among other men. (44)

The role of an Indian wife has been traditionally understood as submissive, docile and that of a homemaker. Sex has been treated as obligatory in a marriage and also taboo to be discussed in public. Research studies indicate that many survivors of marital rape, report sexual dysfunction and emotional pain but they continue living with the abuser. Priyanka Rath in her article Marital Rape and the Indian legal scenario says thus:

Section 375, the provision of rape in the Indian Penal Code (IPC), has been echoing very archaic sentiments, mentioned as its exception clause- "Sexual intercourse by man with his own wife, the wife not being under 15 years of age, is not rape." Section 376 of IPC provides punishment for rape. According to the section, the rapist should be punished with imprisonment of either description for a term which shall not be less than 7 years but which may extend to life or for a term extending up to 10 years and shall also be liable to fine unless the woman raped is his own wife, and is not under 12 years of age, in which case, he shall be punished with imprisonment of either description for a term which may extend to 2 years with fine or with both.

This section in dealing with sexual assault, in a very narrow purview lays down that, an offence of rape within marital bonds stands only if the wife be less than 12 years of age, if she be between 12 to 16 years, an offence is committed, however, less serious, attracting milder punishment. Once, the age crosses 16 , there is no legal protection accorded to the wife, in direct contravention of human rights regulations.

Marital rape is illegal in many countries like America, Australia, New Zealand, Canada, Israel, France, Sweden, Denmark, Norway, Soviet Union, Poland and Czechoslovakia. Unfortunately, Indian law does not have any provisions against marital rape. It is ironical that a woman can protect her right to life and liberty, but not her body, within her marriage.

Passing on from personal customs and traditions, to the governance, it is seen that in a traditional Igbo society, a centralized governmental institution, wielding political power never 
existed. It is quite interesting to note that power was not concentrated in the hands of a few and leadership was less formal. The Igbo people lived in the villages composed of loosely conjoined compounds where families belonging to the same paternal lineage co-existed. Therefore, major disputes and disagreements were handled by the elders themselves and were settled through mutual agreements. Igbo village assemblies have a striking resemblance to our village political system known as Panchayati Raj. Traditionally, it is a south Asian political system, practiced mainly in India, Pakistan and Nepal. It is perhaps the oldest form of administration in India. A group of five wise and respected elders, accepted by the local community, are chosen to settle various problems- intra and inter- village disputes.

To conclude, this study began by initiating a definition about ethnography, its relation with literature, and how Buchi Emecheta, through her texts, reflect the ethnographic writing by presenting the lives of the Igbo people and their culture to a non-Igbo reader. Corresponding to this, a comparison is made between Indian culture and Africa culture and in the process many similarities have been found between both the nations. Notwithstanding this, a few differences have surfaced; for example, the practice of giving Bride Price in Africa has a contrasting parallel in India where the girl's parents, instead of the boy's, give a price (Stridhan) to the bridegroom's family. Another very interesting contrast that was observed is the fact that an Igbo child was never totally an orphan, as he or she always belonged to a particular Onuama in which he was obligatorily helped by the members of the extended family.

The study has revealed that by reading interactively, it is easier to make connections or experience new cultures that are different from one's own. If one is to experience a fusion of horizons with Emecheta's African culture and its traditions, as pointed out by Fishburn, it may be that "we must deny ourselves the more comforting but less challenging temptation of claiming we have already understood her works (xiv)". As one trails through the cross - cultural discussions in Emecheta's novels, "we must be prepared to experience the foreign with the familiar, the perils with the pleasures - else we may find that we have not left home at all" (13). Although this is true regarding a western reader, in the Indian context it is easier for an Indian reader to easily associate with Nigerian culture. Rigney's observation is an interesting fact about Emecheta as a " cross-cultural figure who was born in Nigeria, lives in London, and who draws on African materials and experience, and has been named as one of the best Young British Writers" (189). This observation leaves the readers with a quest for the real identity of the author.

\section{Abbreviations:}

\section{BP- Bride Price}

JOM- Joys of Motherhood

SCC- Second Class Citizens

MU - Marie Umeh

\section{References}

Aligweke, P. (2008). The Continuity of Traditional Values in the African Society: The Igbo of Nigeria. Retrieved from https://books.google.co.in/books?id=sQ89llagUGoC\&printsec=frontcover\&source=gbs_atb\#v=onepage $\& q \& f=$ false

Asad, T. (1990). Ethnography, Literature, and Politics: Some Readings and Uses of Salman Rushdie's The Satanic Verses. Cultural Anthropology, 5(3), 239-269. Retrieved from http://www.jstor.org/stable/656508 
Barthelemy, A. (1989). Western Time, African Lives: Time in The Novels of Buchi Emecheta. Callaloo, (40), summer, 559-574. doi:10.2307/2931303

Chattopadhyay, K. P. (1922). Levirate and Kinship in India. Man, 22(March), 36-41. doi:10.2307/2839641

Davies, C. J. (2002). Black Women, Writing and Identity: Migrations of the Subject. Routledge.

Emecheta, B. (1976). The Bride Price. New York: George Braziller.

---. 1977.The Slave Girl. New York: George Braziller.

---. 1979. In the Ditch.Rev.ed.London. London. London. London. London: Allison and Busby.

---. 1979.The Joys of Motherhood.NewYork: George Braziller.

Emenyonu, E. N. (1988). Technique and Language in Buchi Emecheta's The Bride Price, The Slave Girl and The Joys of Motherhood. The Journal of Commonwealth Literature, 23(March 1), 130-141. doi: https://doi.org/10.1177/o02198948802300112

Gerstein, L. (200o). In India, Poverty and Lack of Education are Associated with Men's Physical and Sexual Abuse of Their Wives. International Perspectives On Sexual And Reproductive Health, 26(1), march, 4445. doi:10.2307/2648290

Gill, S. S. (2008). Modern African literature. New Delhi: Prestige Books.

Ifemesia, C. (1978). Traditional Humane Living Among the Igbo: A Historical Perspective. Nigeria: Fourth Dimension Publishing Company.

Jain, S. (2003). Encyclopaedia of Indian Women through the Ages: Ancient India. Delhi: Gyan Publishing House.

Krishnaswamy, S., \& Kamath, R. (1995). Measurement Of Attitude Toward Inter-Caste Marriage: Development of A Likert-type Scale. International Journal of Sociology of the Family, 25(2), autumn, 125145. Retrieved from http://www.jstor.org/stable/23029669

Okoroike, C. O. (2009). IBOS OF NIGERIA AND THEIR CULTURAL WAYS: Aspects of Behavior, Attitudes, Customs, Language and Social Life. IUniverse. Retrieved from https://books.google.co.in/books?id=Ik2rBG5i8XQC\&dq = Columbus O. Okorike. Ibos of Nigeria and Their Cultural Ways: Aspects of Behaviour, Attitudes, Customs, Language and Social Life.

Okpaku, J. O. (1966). The western Africanist versus the African intellectual: An examination of the present state of African Humanities. Journal of New African Literature and Arts, (2), fall, 1-4. Retrieved from https://books.google.co.in/books?id=lAS2SOS-eMsC\&pg= PA364 \& lpg = PA364 \& dq = The western Africanist versus the African intellectual: An examination of the present state of African Humanities \& source.

Pattanaik, D., Dr. (2014, March 22). Infertility in Hindu Mythology [Web log post]. Retrieved from http://blog.drmalpani.com/2014/o3/infertility-in-hindu-mythology-dr.html.

Rigney, B. H. (2003). Mothering across Cultures: Postcolonial Representations by Angelita Reyes; Writing across Cultures: Gender Politics and Difference in the Fiction of Buchi Emecheta by Omar Sougou. Research in African Literatures, 34(3), 188-19o. Retrieved from http://www.jstor.org/stable/3821271.

Schipper, M. (1985). Women and Literature in Africa. London: Allison and Busby.

Stratton, F. (1988). The Shallow Grave: Archetypes of Female Experience in African Fiction. Research in African Literatures, 19(2), special issue on women's writing, 143-159. Retrieved from http://www.jstor.org/stable/3819444

Umeh, M. (Ed.). (1996). Emerging Perspectives on Buchi Emecheta. New Jersey: Africa World Press. 